\title{
Efisiensi Bank dalam Kelompok BUKU 4 di Indonesia: Pendekatan Data Envelopment Analysis
}

\author{
Nurshadrina Kartika Sari dan Nanda Widaninggar
}

Program Akuntansi Sekolah Tinggi Ilmu Ekonomi (STIE) Mandala

Jl. Sumatera No. 118-120, Jember, 68121, Indonesia

\section{Info Article}

History Article:

Approved: 8 Dcsember 2018

Published: 25 December 2018

Keywords:

Banking efficiency; BUKU 4;

Data envelopment analysis;

Technical efficiency

ISSN (print) : 2598-7763

ISSN (online): 2598-7771

\begin{abstract}
Abtract
This research aims to provide empirical evidence about efficiency level of banks in Indonesia using Data Envelopment Analysis (DEA). DEA is non-parametric analysis which use by this research. This research was conducted using all population of Indonesia banking in BUKU 4 category period 2012 until 2017. Data analysis was conducted for four banking in BUKU 4 category which have core capital more than 30 trillion Rupiah, by using census method. The results provide empirical evidence that Indonesia banking have a 100\%. This research shows that the level of efficiency is able to drive high business results and increase competitiveness for banks in the BUKU 4 category.
\end{abstract}

Citation: Sari, Kartika Nurshadrina dan Widaninggar, Nanda. (2018). Efisiensi Bank dalam Kelompok BUKU 4 di Indonesia: Pendekatan Data Envelopment Analysis. Accounting and Financial Review, 1 (2)

\begin{abstract}
Abstraks
Penelitian ini bertujuan untuk memberikan bukti empiris tentang tingkat efisiensi bank di Indonesia menggunakan Data Envelopment Analysis (DEA). Teknik analisis yang digunakan analisis non-parametrik dengan DEA. Penelitian ini dilakukan dengan menggunakan semua populasi bank Indonesia di BUKU kategori 4 periode 2012 hingga 2017. Analisis data dilakukan untuk empat perbankan dalam kategori BUKU 4 yang memiliki modal inti lebih dari 30 triliun Rupiah, dengan menggunakan metode sensus. Hasilnya memberikan bukti empiris bahwa perbankan Indonesia memiliki 100\%. Penelitian ini menunjukkan bahwa tingkat efisiensi mampu mendorong hasil bisnis yang tinggi dan meningkatkan daya saing bagi bank dalam kategori BUKU 4
\end{abstract}

JEL Classification: C02, C14, C54,G2

DOI: https://doi.org/10.26905/afr.v1i2.2409 $\triangle$ Corresponding Author:

Nurshadrina Kartika Sari

Tel. /Fax. +6285235089814

E-mail: shadrina.kartika@stie-

mandala.ac.id yang tinggi yang akan mampu bersaing dan bertahan. Dalam industri perbankan yang kompetitif, maka bank sebagai pelaku harus sehat. Efisiensi yang tinggi menjadi pilar utama kesehatan bank (Haryanto, 2018).

Industri perbankan yang terkonsentrasi, sehingga tingkat kompetisi yang rendah akan cenderung efisieni juga rendah. Market power bank yang tinggi, dimana industri bank hanya dikuasai oleh beberapa bank besar akan cenderung terjadi kolusi diantara bank dengan market power yang 
besar. Bank-bank tersebut akan dapat menentukan harga. Sehingga bank dengan market power tersebut akan dapat memperoleh profit yang tinggi. Kompetisi industri perbankan di China yang rendah telah mendorong bank tersebut mampu membukukan profit yang tinggi (Tan dan Floros, 2014).

Efisiensi bank dapat mencerminkan kinerja bank dengan membandingkan output yang diperoleh dengan input yang dimiliki bank. Bank yang lebih efisien diharapkan akan cenderung mendapat keuntungan yang optimal, dana pinjaman yang lebih banyak dan dapat memberikan layanan yang lebih baik kepada nasabahnya. Semakin tinggi profitabilitas suatu bank menunjukkan bank tersebut mampu mengelola sumber daya bank untuk memperoleh hasil yang besar (Deanna, 2018).

Pada perbankan nasional kelompok bank umum dibagi menjadi 4 Bank Umum Kelompok Usaha (BUKU), pengelompokkannya berdasarkan jumlah modal inti yang dimiliki masing-masing bank. Kelompok bank yang masuk dalam BUKU 4 selain memiliki modal inti diatas 30 Triliun, bank dalam kelompok ini juga dapat melaksanakan seluruh kegiatan usaha baik di dalam dan diluar negeri (international world wide). Berdasarkan penelitian yang dilakukan oleh Subandi dan Ghozali (2014), Anwar dkk (2012) dan Nurwulan (2012) menyimpulkan bahwa ukuran bank mampu mendorong peningkatan efisiensi bank.

Adapun bank yang berada pada kelompok BUKU 4 pada sampai tahun 2018 adalah Bank Mandiri, Bank BNI, Bank BRI, BCA dan CIMB Niaga. Jumlah modal inti yang besar ditambah dengan simpanan yang dihimpun dari masyarakat menjadikan bank-bank tersebut juga memiliki total aset yang besar.

Ukuran efisiensi bank sendiri dapat terlihat dari dua indikator yaitu rasio perbandingan beban operasional dengan pendapatan operasional (BO$\mathrm{PO})$ dan margin bersih (NIM). Tabel 1 menunjukkan rasio BOPO dan NIM yang dimiliki oleh bank pada kelompok BUKU 4.

Berdasarkan Tabel 1. terlihat bahwa rasio BOPO Bank pada kelompok BUKU 4 mulai tahun 2014 hingga 2017 berada pada presentase $67 \%-75 \%$, sedangkan untuk rasio NIM sendiri bank masih diatas $4,5 \%$. Hal ini mengisyaratkan bahwa bank dari sisi BOPO telah berupaya menekan biaya operasional sehingga dapat meningkatkan pendapatan operasionalnya, disisi lain NIM yang diperoleh bank juga menunjukkan adanya trend positif selama jangka waktu 2014-2018 hal ini menun- jukkan bank mampu menghasilkan keuntungan atas penyaluran kredit dan kegiatan operasionalnya. Sehingga bila dikaitkan rasio BOPO yang semakin rendah akan mampu mendorong peningkatan NIM bank.

Tabel 1. Indikator Efisiensi Bank Kelompok BUKU 4

\begin{tabular}{llllll}
\hline Indikator & 2014 & 2015 & 2016 & 2017 & $\begin{array}{l}\text { Ketentuan } \\
\text { BI }\end{array}$ \\
\hline BOPO & 67,10 & 70,46 & 75,05 & 70,31 & $\geq 75 \%$ \\
NIM & 5,10 & 6,36 & 6,50 & 5,99 & $\geq 4,5 \%$ \\
\hline
\end{tabular}

Menurut Qurniawati (2013) BOPO merupakan rasio yang sering digunakan karena kemudahan pengukurannya, namun rasio ini juga memiliki kelemahan yaitu kurang mampu menggambarkan kondisi bank yang sebenarnya dan hasil penilaiannya tidak mudah diinterprestasikan.

Untuk mengatasi kelemahan rasio $\mathrm{BOPO}$ diperlukan penggunaan pengukuran efisiensi perbankan yang mampu menggambarkan kondisi bank yang sebenarnya. Bank dalam proses bisnisnya banyak menggunakan input dan juga output, sehingga penggunaan BOPO untuk mengukur efisiensi kurang mampu mencerminkan efisien bank (Firdaus dan Hosen, 2013). Pengukuran efisiensi harusnya juga mengikutsertakan seluruh input dan output yang digunakan bank dalam proses produksinya, sehingga dapat diperoleh hasil yang lebih riil. Analisis untuk mengukur efisiensi ada dua yaitu secara parametrik dan non-parametrik, Data Envelopment Analysis (DEA). Analisis efisiensi menggunakan DEA diyakini sebagai comprehensive efficiency, sedangkan analisis menggunakan BOPO cenderung merupakan partial efficiency (Firdaus dan Hosen, 2013).

Penelitian ini bertujuan untuk 1) memperoleh nilai efisiensi Bank dalam Kelompok BUKU 4 dengan menggunakan analisis DEA dan 2) mengidentifikasikan apakah Bank dalam Kelompok BUKU 4 tersebut efisien atau tidak.

\section{PENGEMBANGAN KERANGKA PIKIR}

Sektor perbankan memiliki peran yang vital bagi perekenomian suatu negara, dalam rangka menggerakkan roda perekonomian dan mampu bersaing dengan usaha sejenis sektor perbankan selalu berupaya meningkatkan kinerja yang dimilikinya dari waktu ke waktu. Pemerintah juga memberlakukan berbagai kebijakan untuk menstimulus kinerja sektor ini. Selain itu, kinerja bank sendiri merupakan tolak ukur keberhasilan manajemen.

Sebagai alat ukur kinerja, efisiensi merupakan kemampuan menghasilkan output yang opti- 
mal dengan input yang dimiliki oleh perusahaan. Pemisahan alokasi input dan output dapat menunjukkan penyebab inefisiensi suatu perusahaan. Pada sektor perbankkan Bank Indonesia mengukur kinerja bank dengan menggunakan rasio permodalan (capital), kualitas aset (assets quality), manajemen (management), laba (earning) dan likuiditas (liquidity) atau yang disebut dengan CAMELS.

Analisis efisiensi terdiri dari dua yaitu dengan analisis parametrik dan analisis nonparametrik. Analisis parametrik yang dikembangkan oleh Meeusen dan Broek (1977) dan Aigner, dkk. (1977) adalah Stochastic Frontier Approach (SFA), sedangkan analisis non-parametrik yang dikembangkan oleh Charnes dan Rhodes (1978) adalah Data Envelopment Analysis (DEA). Kedua analisis tersebut telah digunakan oleh Sivia dkk (2016) untuk mengetahui tingkat efisiensi pada Bank lokal di Cina. Hasil yang ditemukan adalah kedua analisis menunjukkan informasi efisiensi bank yang stabil secara keseluruhan, tapi menjadi beragam ketika pada level individual. Untuk dapat mengukur dengan kedua analisis tersebut harus ditentukan terlebih dahulu input dan outputnya.

Prosedur yang dibangun melalui analisis DEA secara khusus terdapat cara untuk mengukur efisiensi relatif suatu Decision Making Unit (DMU) yang menggunakan banyak input dan output. Terdapat dua model yang sering diguna-kan dalam analisis DEA, yang pertama dengan menggunakan model Charnes, Cooper and Rhodes (CCR) dan yang kedua model Banker, Charnes dan Cooper (BCC).

Pada model CCR dimana menghasilkan sebuah evaluasi objektif dari keseluruhan efisiensi dan mengidentifikasi ketidakefisienan yang terjadi (Pawlowska, 2003). CCR merupakan rasio dari total output tertimbang dibagi total input tertimbangnya, dimana bobot yang digunakan bersifat tidak bernilai negatif dan bersifat universal. Pada setiap DMU yang dimiliki akan memilih bobot yang memaksimumkan rasio efisiensinya, hal ini karena efisiensi yang tercermin merupakan bentuk penghematan input yang bisa dilakukan unit yang dievaluasi tanpa harus mengurangi level output ataupun adanya penambahan output yang diselalu berasal dari penambahan input (Purwantoro, 2003). Asumsi perbandingan input dan output suatu perusahaan tidak mempengaruhi produktivitas yang mungkin dicapai, asumsi ini disebut dengan Constant Return to Scale (CRS).

Ukuran efisiensi DMU dapat dihitung dengan menyelesaikan permasalahan programming matematika (Sulistyono, 2013). Model yang digu- nakan sebagai berikut:

$$
\begin{aligned}
& \operatorname{Max} Z o=\frac{\stackrel{s}{r}=1 \text { vy } r 10}{s} \\
& i=1 U i X i 0
\end{aligned}
$$

Subject to

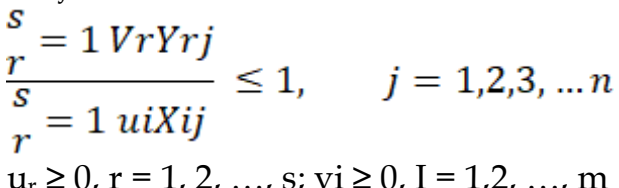

dengan $x_{i j}$ adalah nilai input yang diamati dengan tipe ke-i dari DMU ke-j dan $x_{i j}>0$ untuk $I=1,2,3, \ldots$ $m$ dan $j=1,2, \ldots n$. Demikian juga dengan $y_{r j}>0$ untuk $\mathrm{I}=1,2, \ldots, \mathrm{m}$ dan $\mathrm{j}=1,2, \ldots, \mathrm{n}$

Model kedua yaitu BCC mengasumsikan bahwa peningkatan input tidak menghasilkan perubahan pada output yang proposional sehingga disebut dengan Variable Return to Scale (VRS), model ini merefleksikan kinerja manajemen untuk mengorganisir input dalam proses produksi $(\mathrm{Ku}-$ mar dan Gulati, 2008). VRC menggambarkan technical efficiency secara keseluruhan yang terdiri dari dua komponen pure technical efficiency dan scale efficiency. Dengan konsep VRS yang berorientasi pada output, maka digunakan formula sebagai berikut (Handoyo, 2008) seperti model 1.

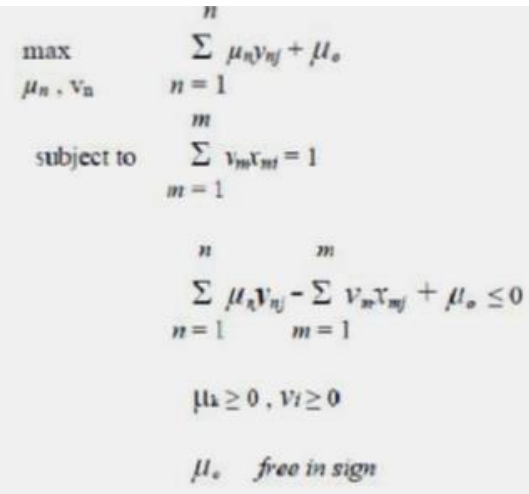

Model 1. Konsep VRS yang berorientasi pada output

Menurut Cooper dan Tone (2007) konstanta $\mu$ o bertanda bebas, yakni dapat bernilai positif ataupun negatif, konstanta dalam rumus VRS di atas menyebabkan penambahan input sebesar $x$ kali tidak akan menyebabkan output meningkat sebesar x kali pula, melainkan dapat lebih kecil atau lebih besar dari $x$ kali. Apabila $\mu$ o benilai positif output mengalami peningkatan, namun apabila negative maka output mengalami penurunan.

Pengukuran kinerja pada suatu perusahaan adalah melalui tingkat efisiensi yang bisa dicapai oleh perusahaan tersebut, tidak terkecuali pada sektor perbankan. Perusahaan dikatakan efisien pada saat mampu peroperasi dengan input yang 
tersedia dan menghasilkan output yang maskimal. Salah satu analisis yang dapat digunakan untuk menguru tingkat efisiensi perusahaan adalah DEA. Dengan analisis DEA melalui pendekatan yang mendefinisikan hubungan input dan output dalam tingkah laku sektor perbankan. Pada penelitian ini input yang digunakan adalah beban administrasi, beban personalia, beban operasional lain, beban bunga, dana pihak ketiga, laba sebelum pajak, total deposit dan komisi yang dibayarkan, sedangkan output yang dipakai adalah Penempatan dana antar bank, surat berharga, kredit yang diberikan, pendapatan bunga, pendapatan operasional lainnya dan komisi yang diterima.

\section{DATA DAN METODE}

\section{Data Penelitian}

Analisis penelitian dikembangkan berdasarkan kerangka teori seperti disajikan pada Gambar
1. Input bank, berupa biaya yang harus dikeluarkan bank. Output bank berkaitan dengan pendapatan bunga dan non bunga.

Data yang digunakan pada penelitian ini adalah laporan keuangan bank-bank yang berada pada kelompok BUKU 4 di Indonesia, kolompok ini memiliki modal inti lebih dari 30 Triliun dan telah ditetapkan oleh Bank Indonesia selama periode 2012-2017. Bank dalam kelompok BUKU 4 memiliki kelebihan diantaranya tingkat keamanan, kekuatan dalam menghadapi permasalahan operasionalnya, dinilai lebih sehat dan memiliki risiko bisnis yang lebih rendah. Sampel penelitian yang akan dipilih adalah seluruh bank yang berada pada Kategori BUKU 4 dengan menggunakan metode sensus.

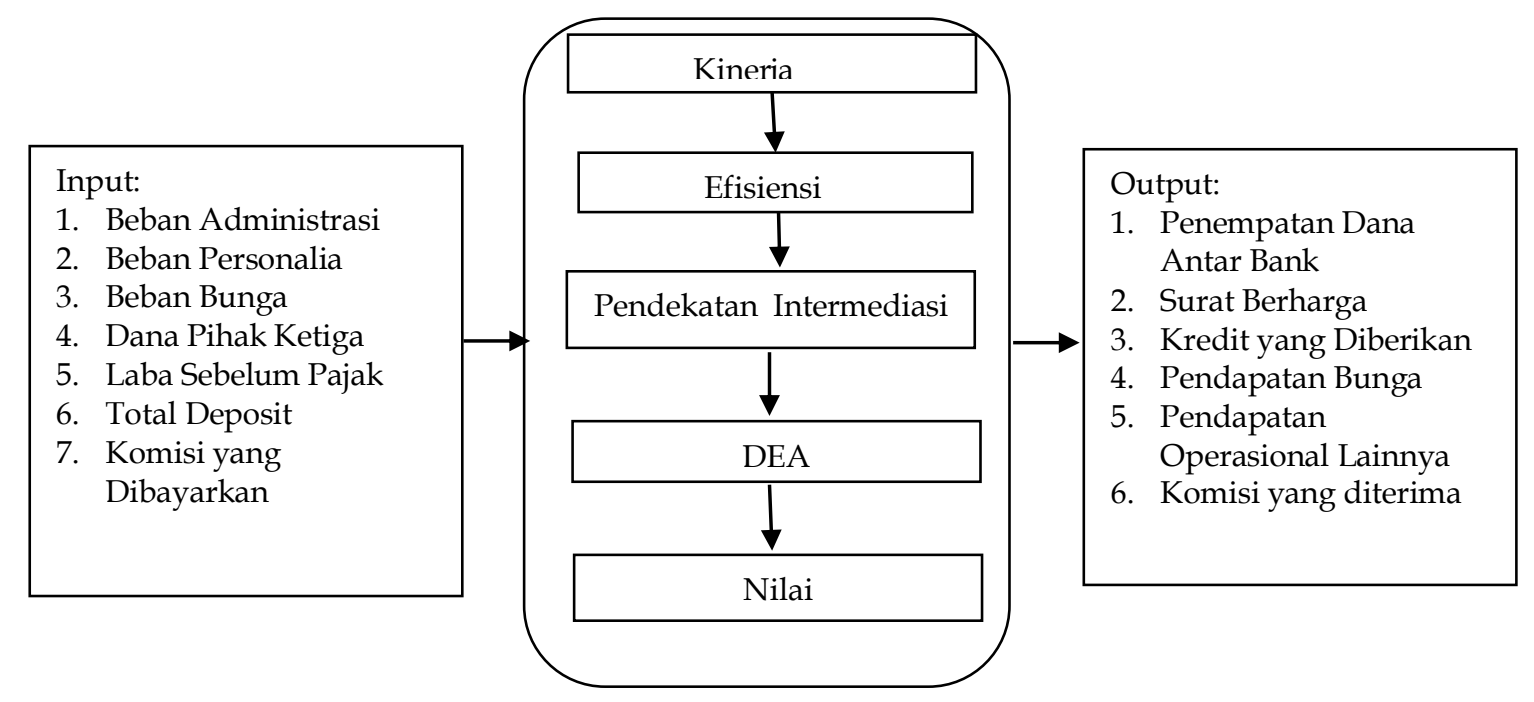

Gambar 1 Kerangka Teori

\section{Sampel Penelitian}

Sampel penelitian mengambil sebanyak 4 bank. Bank yang menjadi sampel merupakan bank dengan jumlah asset yang tersbesar di Indonesia (Tabel 2). Berdasarkan aset bank, bank BUMN masih menjadi bank dengan asset yang terbesar. Sedangkan bank swasta hanya Bank BCA yang mimiliki asset besar.

Tabel 2. Sampel Penelitian

\begin{tabular}{lc}
\hline Nama Bank & Modal Inti Tahun 2017 (miliar Rupiah) \\
\hline BCA & 122.730 \\
BNI & 89.765 \\
BRI & 93.436 \\
MANDIRI & 145.616 \\
\hline
\end{tabular}

\section{Metode Analisis Data}

Penelitian ini menggunakan Data Envelopment Analysis (DEA) dengan langkah-langkah pengulahan sebagai berikut (Gunawan dan Utiyati, 2013): 1) Menentukan variabel input dan output yntuk diperhitungkan dalam proses analisis. 2) Mengelola data yang ada dengan DEA menggunakan software MaxDEA dengan melalui dua tahapan. Tahap 1: mempersiapkan data (DMU, input dan output) ditentukan dan dikemas ke dalam tabel yang kemudian akan diproses pada tahap 2.

Tahap 2: Run Model, data yang telah disiapkan pada tahap 1 diproses sesuai dengan metode 
dan pendekatan Variabel Return to Scale (VRS) dengan pendekatan output-oriented. Hasil tahap 2 ditampilkan dalam bentuk result table. Menginterpresentasikan hasil olahan data yang dihasilkan DEA, pada tahap ini akan diuraikan DMU mana yang efisien dan inefisien serta cara memperbaiki dengan melihat multiplier dan nilai target yang dihasilkan DMU yang menjadi acuan.

Hasil perhitungan tersebut kemudian digunakan untuk menganalisis dan menyusun kesimpulan terkait nilai efisiensi teknis untuk seluruh unit. Skor efisiensi untuk setiap unit nilainya 0 dan 1. Dengan ketentuan nilai 1 menunjukkan efisiensi yang sempurna atau sampel dianggap memiliki nilai efisien $100 \%$ dan dianggap tidak efisien apabila kurang dari 1 (Abidin dan Endri, 2009).

\section{HASIL}

Setelah menentukan variabel input dan output, maka disusunlah data yang terdiri dari DMU, input dan output yang disusun kedalam bentuk tabel untuk diproses ke dalam aplikasi MaxDEA. Pada penelitian ini terdapat 24 DMU yang terdiri dari 6 DMU BCA periode 2012-2017, 6 DMU BNI periode 2012-2017, 6 DMU BRI periode 2012-2017 dan 6 DMU Bank Mandiri periode 2012-2017.

Data diproses sesuai dengan metode dan pendekatan Variabel Return to Scale (VRS) dengan pendekatan output-oriented. Hasil analisis ditampilkan dalam bentuk result table. DMU dalam penelitian ini menunjukkan hasil efisiensi bank yang sangat baik yaitu Efisiensi tinggi dengan score 1 atau $100 \%$. Nilai efisiensi bank ini diperoleh dari suatu kondisi dimana input yang dimiliki berupa beban administrasi, beban personalia, beban bunga, DPK, laba sebelum pajak/ EBIT, total deposit dan komisi yang dibayarkan sebanding dengan output yang diperoleh yaitu penempatan dana antar bank, surat berharga, kredit yang diberikan, pendapatan bunga, pendapatan operasional lainnya dan komisi yang diterima.

Tabel 3. Ringkasan Hasil Envelopment Mode Bank pada Kelompok BUKU 4

\begin{tabular}{cllllllll}
\hline No. & \multirow{2}{*}{ Bank } & 2012 & 2013 & 2014 & 2015 & 2016 & 2017 & Kesimpulan \\
\hline 1 & BCA & 1,00 & 1,00 & 1,00 & 1,00 & 1,00 & 1,00 & Efisien \\
2 & BNI & 1,00 & 1,00 & 1,00 & 1,00 & 1,00 & 1,00 & Efisien \\
3 & BRI & 1,00 & 1,00 & 1,00 & 1,00 & 1,00 & 1,00 & Efisien \\
4 & MANDIRI & 1,00 & 1,00 & 1,00 & 1,00 & 1,00 & 1,00 & Efisien \\
\hline
\end{tabular}

\section{PEMBAHASAN}

Bank pada Kelompok BUKU 4 merupakan kelompok bank yang memiliki modal inti lebih dari 30 Triliun berdasarkan keputusan Bank Indonesia. Bank yang masuk kelompok bank dalam BUKU 4 memiliki kelebihan diantaranya bank memiliki tingkat keamanan dan kekuatan dalam menghadapi permasalahan operasionalnya.

Hasil penelitian ini menyimpulkan bahwa 4 bank yang termasuk kedalam Kelompok BUKU 4 selama periode 2012 hingga 2017 memiliki tingkat efisiensi $100 \%$. Hal ini menunjukkan bahwa selama menjalankan kegiatan operasionalnya sebagai lembaga intermediasi bank-bank ini telah mampu mengoptimalkan penggunaan input yang dimilikinya guna memperoleh output yang diharapkan.

Bank yang berada pada Kelompok BUKU 4 dapat dikategorikan sebagai bank dengan ukuran aset yang besar, semakin besar sumber daya yang dimiliki bank akan meningkatkan kemampuan bank dalam memaksimalkan kegiatan operasionalnya, sehingga efisiensi mampu dicapai. Nurwulan (2013), Barry, dkk. (2010) dan Nafti, et.al. (2017),
Noor \& Ahmad (2009) menemukan bahwa bank dengan skala usaha dan modal yang besar berhubungan positif terhadap efisiensi. Temuan penelitian ini sejalan dengan temuan penelitian Fathony (2013), Rezitis (2006), Bos dan Kolari (2005) dimana, bank dengan asset yang semakin besar, akan cenderung semakin efisien.

Temuan penelitian ini menunjukkan bahwa bank dengan asset yang besar mampu menggunakan economic of scale. Dimana bank yang besar mampu mengoptimalkan sumber daya yang dimiliki, untuk meningkatkan pendapatannya. Bank yang besar cenderung memiliki Jumlah kantor cabang yang banyak dan tersebar serta teknologi yang lebih baik, sehingga bank tersebut memiliki kemampuan untuk menghimpun dana masyarakat (DPK) yang semakin besar.

Kepercayaan dan pelayanan menjadi modal yang sangat penting dalam bisnis perbankan. Kepercayaan masyarakat terhadap bank akan cenderung tinggi pada bank besar. Bank yang besar akan memiliki sumber daya yang lebih baik untuk memberikan pelayanan pada nasabahnya. Sehingga bank-bank besar akan mampu menekan biaya 
dananya. Tingkat bunga simpanan bank besar cenderung lebih rendah dibandingkan dengan bankbank kecil. Di sisi lain, dengan jumlah kantor cabang yang lebih banyak dan tersebar, bank besar akan memiliki potensi untuk menyalurkan kredit yang semakin besar. Kemampuan menyalurkan kredit bank besar, ditopang oleh DPK yang besar.

Pengukuran efisiensi dengan menggunakan DEA berbeda dengan rasio BOPO, yaitu rasio BOPO hanya menandingkan beban operasional dengan pendapatan operasional secara keseluruhan, sedangkan pendekatan DEA mampu mengukur efisiensi pada tiap DMU dengan bermacam-macam input dan output mampu dibobotkan tanpa harus ditentukan diawal. Menurut Qurniawati (2013) input dan output yang digu-nakan dalam DEA dapat mengukur inefisiensi unit-unit yang menjadi pengamatan dengan unit lain yang dianggap paling efisien dalam data tersebut. Selain itu DEA juga mampu menunjukkan sumber ketidakefisienan dengan ukuran peningkatan potensial dari masingmasing input.

\section{KESIMPULAN DAN SARAN}

Berdasarkan hasil penelitian menemukan bahwa 1) seluruh Bank dalam Kelompok BUKU 4 selama periode 2012-2017 dengan menggunakan analisis DEA bernilai 100\% efisien dan 2) seluruh bank dalam Kelopok BUKU 4 menjalankan kegiatan operasionalnya selama periode 2012-2017 secara efisien.

Penelitian ini hanya menggunakan bank pada kelompok BUKU 4, untuk itu penelitian selanjutnya dapat menambahkan bank pada kelompok BUKU 1 hingga 3 dan membandingkan tingkat efisiensi secara keseluruhan untuk memperoleh gambaran utuh tentang tingkat efisiensi seluruh bank di Indonesia.

\section{DAFTAR PUSTAKA}

Abidin, Z. dan Endri. (2009). Kinerja Efisiensi Bank Pembangunan Daerah: Pendekatan Data Envelopment Analysis (DEA). Jurnal Akuntansi dan Keuangan. 11(1): 21-29.

Andries, A. M., dan Capraru, B. (2012). Competition and efficiency in EU 27 banking system. Baltic Journal of Economics, 12(1): 41-60.

Anwar, M., dkk. 2012. Small Business Finance and Indonesian Banks Efficiency: DEA Approach. The $13^{\text {th }}$ International Convention of The East Asian Economic Association.

Aigner, D.J., Knox, L and Schmidt, P. (1977). For- mulation and Estimation of Stochatic Frontier Production Function Models. Econ. Rev. 6: 2337.

Barry, A.T., Dacanay, J.S.O., Lepetit, L. and Tarazi, A. (2010). Ownership Structure and Bank Efficiency in Six Asian Countries. Philippine Management Review (Special Isue). 18: 19-35.

Bos, J.W. dan Kolari, J. (2005). Large Bank Efficiency in Europe and the United States: Are There Economics Motivations for Geographic Expansion in Financial Service? The Journal of Business. 78(4).

Charnes, A., Cooper dan Rhodes, E. (1978). Measuring the Efficiency of Decision Making Units. European Journal of Operational Research. 2: 429444.

Cooper, W.W., L.M, Seiford dan K. Tone. (2007). Data Envelopment Analysis: A Comprehensive Text with Models, Application. Reference and DEA-Solver Software. Second. Springer.

Deanna, N.J. (2018). Determinan Efisiensi Operasional Perbankan Indonesia (Studi Empiris pada Perbankan Umum Konvensional di Indonesia). Jurnal Muara Ilmu Ekonomi dan Bisnis. 2 (1): 218-225.

Fathony, M. (2013). Analisis Efisiensi Perbankan Nasional Berdasarkan Ukuran Bank: Pendekatan Data Envelopment Analysis. Finance and Banking Journal. 15 (1)

Firdaus, F.M. dan Hosen, N.M. (2013). Efisiensi Bank Umum Syariah Menggunakan Pendekatan Two-Stage Data Envelopment Analysis. Buletin Ekonomi Moneter dan Perbankan. Oktober 2013: 167-188.

Gunawan, F.A. dan Utiyati, S. (2013). Analisis Tingkat Efisiensi Bank BUMN dengan Pendekatan Data Envelopment Analysis (DEA). Jurnal Ilmu dan Riset Manajemen. 2(8): 1-17.

Handoyo, R. D. (2008). Modul in House Training Mahasiswa Data Envelopment Analysis. Departemen Ilmu Ekonomi Fakultas Ekonomi Universitas Airlangga Surabaya.

Haryanto, S. (2018). Determinan Efisiensi Bank: Analisis Bank Di Indonesia. Accounting and Financial Review, 1(1)

Kumar, S dan Gulati, R. (2008). An Examination of Technical, Pure Technical and Scale Efficiencies in Indian Public Sector Banks Using Data Envelopment Analysis. Eurasian Journal of 
Business and Economics. 1(2): 33-69.

Meeusen, W. dan Broeck, J. (1977). Efficiency Estimation from Cobb-Douglas Production Functions with Composed Error. Int. Econ. Rev. 18: 435-444.

Nafti, O., Boumediene, L.S., Khouaja, S and Ayed, B.W. (2017). The Determinants Of World Islamic Banks Efficiency: Empirical Analysis Using A Non Parametric Approach. The Journal of Applied Business Research. 33(2): 363-374

Noor, M.A., dan Ahmad, N.H. (2009). The Determinants of World Islamic Banks' Efficiency and The Impact of 1998 and 2008 Financial Crisis. Universiti Utara Malaysia.

Nurwulan. (2012). Analisis Pengaruh Bank Size, NPL, ROA, Kapitalisasi dan CAR terhadap Efisiensi Perbankan. Tesis. Semarang: Universitas Diponegoro.

Pawlowska, M. (2003). The Impact of M \&A on Technical Efficiency, Scale Efficiency and Productivity Change in The Polish Banking Sector: a Non-Parametric Approach. National Bank of Poland, Materialy I Studia, Paper No. 29.

Purwantoro, N. (2003). Penerapan DEA dalam Kasus Pemilihan Produk Inkjet Personal Printer. Usahawan. 10: 36-41.

Qurniawati, R.S. (2013). Efisiensi Perbankan di Indonesia dan Pengaruhnya terhadap Return Saham dengan Pendekatan Data Envelopment Analysis (DEA). Benefit Jurnal Manajemen dan Bisnis. 17(1): 27-40.
Rezitis, N.A. (2006) Productivity Growth in the Greek Banking Industry: A Non Parametric Approach. Journal of Applied Economics. 9(1).

Subandi dan Ghozali, I. (2014). A Efficiency Determinant of Banking Industry in Indonesia. Research Journal of Finance and Accounting. 5(3).

Sulistyono, B. (2014). Pengukuran Efisiensi Bank BUMN di Indonesia dengan Menggunakan Metode Data Envelopment Analysis. Research Gate. https://www.researchgate.net/ publication/278968402

Tan, Y., dan Floros, C. (2014). Risk, profitability, and competition: Evidence from the Chinese banking industry. Journal of Developing Areas. 38(3): 303-319.

Yusniar, M.W. (2011). Analisis Efisiensi Industri Perbankan di Indonesia dengan Pendekatan Data Envelopment Analysis (DEA) dan FaktorFaktor yang Mempengaruhinya. Jurnal Manajemen dan Bisnis. 1(2). 